\title{
Electrochemical synthesis of diaminodicarboxylic acid derivatives
}

\author{
Paula M. T. Ferreira, Hernâni L. S. Maia and Luís S. Monteiro* \\ Department of Chemistry, University of Minho, Gualtar, P-4710-057 Braga, Portugal \\ Received 19 December 2002; accepted 15 January 2003
}

\begin{abstract}
Diaminoadipic acid derivatives were synthesized in good yields by electrolysis of $N, N$-diacyldehydroalanines. Cyclic voltammetry measurements on the precursors are presented and interpreted as supporting formation of a nucleophilic intermediate generated by electrochemical reduction. (C) 2003 Elsevier Science Ltd. All rights reserved.
\end{abstract}

\section{Introduction}

Diaminodicarboxylic acid derivatives (bis-amino acids) are an important class of biologically active compounds. 2,6-Diaminopimelic acid is the key cross-linking amino acid in the cell wall peptidoglycan layer in many Gram-negative organisms and a precursor of lysine, which is formed via this intermediate in many Gram-positive organisms. ${ }^{1,2}$ These diaminodicarboxylic acid derivatives give rise to conformational constraints stabilizing the secondary structures of peptides, ${ }^{3}$ and have also been used as building blocks for development of peptidomimetics. ${ }^{4}$

The methods described for the synthesis of these compounds are generally multi-step and/or low yielding. The electrochemical synthesis of diaminodicarboxylic acid derivatives using Kolbe electrolysis has been described by Hiebl et al. ${ }^{5}$ In this work oxidative decarboxylation of aspartic and glutamic acid derivatives gave rise to a radical intermediate, which produced 2,5-diaminoadipic acid and 2,7-diaminosuberic acid derivatives by dimerization, but only low yields were obtained. Now, we describe a single step electrochemical method for the synthesis of 2,5-diaminoadipic acid derivatives in good yields using $N, N$-diacyldehydroalanine derivatives as starting materials.

\footnotetext{
Keywords: dehydroamino acids; cyclic voltammetry; electrolysis; diaminodicarboxylic acids; 2,5-diaminoadipic acid.

* Corresponding author. Fax: 351253 678983; e-mail: monteiro@ quimica.uminho.pt
}

\section{Results and discussion}

Following previous results obtained in the electrochemical cleavage of the $p$-toluenesulfonyl (tosyl, Tos) and $p$-nitrobenzyloxycarbonyl $\left[\mathrm{Z}\left(\mathrm{NO}_{2}\right)\right]$ groups from $N, N$ diacyldehydroalanine and $N, N$-diacyldehydroaminobutyric acid derivatives, ${ }^{6}$ we decided to investigate further the electrochemical behaviour of dehydroamino acid derivatives. Thus, the activation potentials of several $N$-acyl- and $N, N$-diacyldehydroamino acid derivatives (Table 1, entries 4-6 and 7-9, respectively) were determined by cyclic voltammetry and compared with those for the respective $\beta$-hydroxyamino acid derivatives (Table 1 , entries $1-3)^{7}$

As expected from our previous experience, ${ }^{8}$ the peak potentials found with all the $\mathrm{Z}\left(\mathrm{NO}_{2}\right)$ amino acid derivatives investigated fell within a fairly narrow range $(0.15$ $\mathrm{V})$; the reduction potential of this group is not affected by the neighbourhood of either a tert-butyloxycarbonyl group (Boc) group or a double bond. However, this was not the case of both benzoyl (Bz) and tosyl dehydroamino acid derivatives, which exhibit reduction potentials shifted to significantly less negative values than those of the corresponding $\beta$-hydroxyamino acid compounds. We assign this behaviour to stabilisation of the radical anion by conjugation of the aromatic ring of these two groups with the $\alpha, \beta$-double bond (entries 4-6) and with the Boc carbonyl group (entries 7-9), which would not occur in the case of the nitrophenyl species. This effect is enhanced in the dehydrophenylalanine $(\Delta \mathrm{Phe}$ ) series (entries 3, 6 and 9) by further conjugation with the amino acid $\beta$-phenyl ring and markedly weakened in the dehydroaminobutyric acid $(\triangle \mathrm{Abu})$ series (entries 1,4 and 7 ), certainly due to the electron donating effect of the $\beta$-methyl group. 
Table 1. Peak potentials obtained by cyclic voltammetry of amino acid and dehydroamino acid derivatives ${ }^{\mathrm{a}}$

\begin{tabular}{|c|c|c|c|c|c|c|c|}
\hline & \multirow[t]{2}{*}{ Compound } & \multirow[b]{2}{*}{$\mathrm{P}$} & \multicolumn{5}{|c|}{$-E p(\mathrm{~V}$ versus S.C.E.) } \\
\hline & & & $\mathrm{Z}\left(\mathrm{NO}_{2}\right)$ & $\mathrm{Bz}$ & Tos & $\mathrm{Z}$ & Boc \\
\hline 1 & P-Thr-OMe & & 1.14 & 2.36 & 2.50 & 2.82 & $\mathrm{~b}$ \\
\hline 2 & P-Ser-OMe & & 1.04 & 2.42 & 2.48 & 2.86 & $\mathrm{~b}$ \\
\hline 3 & $\mathrm{P}-\mathrm{Ph}(\beta-\mathrm{OH})-\mathrm{OMe}$ & & 1.08 & 2.38 & 2.53 & & $\mathrm{~b}$ \\
\hline 4 & $\mathrm{P}-\Delta \mathrm{Abu}-\mathrm{OMe}$ & & 0.97 & 2.21 & 2.18 & 2.34 & 2.46 \\
\hline 5 & $\mathrm{P}-\Delta$ Ala-OMe & & 1.10 & 1.91 & 1.90 & 2.29 & 2.12 \\
\hline 6 & $\mathrm{P}-\Delta \mathrm{Phe}-\mathrm{OMe}$ & & 1.12 & 1.87 & 1.65 & & 1.84 \\
\hline 7 & $\mathrm{P}-\Delta \mathrm{Abu}(N-\mathrm{Boc})-\mathrm{OMe}$ & & 1.02 & 2.02 & 2.12 & 2.19 & 2.36 \\
\hline 8 & $\mathrm{P}-\Delta \mathrm{Ala}(N-\mathrm{Boc})-\mathrm{OMe}$ & & 1.04 & 1.84 & 1.88 & 2.04 & 2.01 \\
\hline 9 & $\mathrm{P}-\Delta \mathrm{Phe}(N-\mathrm{Boc})-\mathrm{OMe}$ & & 1.02 & 1.80 & 1.74 & & 1.84 \\
\hline
\end{tabular}

${ }^{a}$ Cathode: vitreous carbon. Solvent: dimethylformamide. Supporting electrolyte: $\mathrm{Bu}_{4} \mathrm{NBF}_{4} 0.1 \mathrm{~mol} \mathrm{dm}^{-3}$. Substrate conc.: $\approx 0.005 \mathrm{~mol} \mathrm{dm}^{-3}$.

${ }^{\mathrm{b}}$ No reduction peak was detected.

All cyclic voltammograms were consistent with irreversible processes occurring after formation of the radical anions, and previous results obtained in electrolyses of $\mathrm{Z}\left(\mathrm{NO}_{2}\right)$ and Tos in $N, N$-diacyldehydroalanine and dehydroaminobutyric acid derivatives showed that these two protecting groups undergo cleavage at the peak potentials listed in Table $1 .^{6}$ However, cyclic voltammograms for dehydroamino acids mono and diacylated with Boc showed peak potentials between -1.84 and $-2.46 \mathrm{~V}$ versus S.C.E. Since this group is stable to electrochemical reduction, ${ }^{8}$ the irreversible voltammograms found for these compounds could not be related to cleavage of Boc. In addition, once the aromatic ring of $\mathrm{Z}$ is not conjugated with the rest of the molecule, potential shifts of $0.63 \mathrm{~V}$ or more would be related to the $\alpha, \beta$-double bond in conjugation with at least two carbonyl groups, and not to the protecting group.

In view of the cyclic voltammetry data now obtained, controlled potential electrolysis of $\operatorname{Boc}-\Delta \mathrm{Ala}(N$-Boc)$\mathrm{OMe}$ and $\mathrm{Z}-\Delta \mathrm{Ala}(N$-Boc)-OMe at the peak potentials indicated in Table 1 was carried out. With both substrates, a 2,5-diaminoadipic acid derivative was isolated in good yields $(85 \%$ and $78 \%$, respectively) as diastereomeric mixtures. ${ }^{9}$ We believe that the reaction proceeds via formation of a carbanion at the $\beta$-carbon atom, which acts as a nucleophile and adds to a molecule of the starting material. In fact, no such reaction was found with Boc- $\Delta$ Ala-OMe and Boc$\Delta \mathrm{Phe}(N$-Boc)-OMe, which are known not to be sufficiently strong electrophiles to undergo nucleophilic attack $^{10}$ (electrolysis of the former resulted in decomposition of the starting material without formation of the diaminoadipic acid derivative). In addition, electrolysis of Boc- $\Delta \mathrm{Phe}(N$-Boc)-OMe gave Boc- $\Delta$ Phe-OMe due to cleavage of one of the Boc groups by electrochemically generated bases.

Thus, electrochemical reduction of $\operatorname{Boc}-\Delta \operatorname{Ala}(N$-Boc)OMe and Z- $\Delta \mathrm{Ala}(N$-Boc)-OMe constitutes a valuable method for the preparation of 2,5-diaminoadipic acid derivatives.

\section{Acknowledgements}

We wish to thank the Fundação para a Ciência e a Tecnologia for financial support (project no. POCTI/ 1999/QUI/32689).

\section{References}

1. Roberts, J. L.; Chan, C. Tetrahedron Lett. 2002, 43, 7679-7682.

2. Paradisi, F.; Porzi, G.; Rinaldi, S.; Sandri, S. Tetrahedron: Asymmetry 2000, 11, 1259-1262.

3. Hiebl, J.; Kollmann, H.; Rovenszky, F.; Winkler, K. J. Org. Chem. 1999, 64, 1947-1952.

4. Sutherland, A.; Vederas, J. C. Chem. Commun. 2002, 224-225.

5. Hiebl, J.; Blanka, M.; Guttman, A.; Kollmann, H.; Leitner, K.; Mayrhofer, G.; Rovenszky, F.; Winkler, K. Tetrahedron 1998, 54, 2059.

6. Ferreira, P. M. T.; Maia, H. L. S.; Monteiro, L. S.; Sacramento, J. J. Chem. Soc., Perkin Trans. 1 1999, 3697-3703.

7. Cyclic voltammetry experiments were carried out using a Hi-Tek potentiostat type DT 2101, and a Hi-Tek wave generator type PPR1, connected to a Philips recorder type PM 8043 and to a three electrode, home-built glass cell.

8. Maia, H. L. S.; Monteiro, L. S.; Degerbeck, F.; Grehn, L.; Ragnarsson, U. J. Chem. Soc., Perkin Trans. 2 1993, $495-500$.

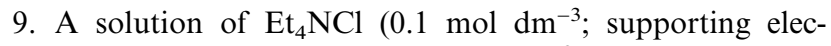
trolyte) and $\mathrm{Et}_{3} \mathrm{NHCl}\left(0.04 \mathrm{~mol} \mathrm{dm}^{-3}\right.$; proton donor) in $\mathrm{MeCN}$ was added to a three-electrode cell. To its cathodic compartment Boc- $\Delta \mathrm{Ala}(N$-Boc)-OMe (150.5 $\mathrm{mg}, 0.5 \mathrm{mmol}$ ) was added and a cyclic voltammogram recorded. The potential was adjusted to a value $50 \mathrm{mV}$ more negative than that corresponding to the $\mathrm{CV}$ peak and the electrolysis started, the reaction being monitored by HPLC. When all starting material had disappeared, the content of the cathodic compartment was concentrated at reduced pressure and the residue partitioned between $100 \mathrm{~cm}^{3}$ of ethyl acetate and $50 \mathrm{~cm}^{3}$ of citric acid $5 \%$. The organic phase was then washed with citric acid 
$5 \%, \mathrm{NaHCO}_{3} 1 \mathrm{~mol} \mathrm{dm}{ }^{-3}$ and brine (three times $30 \mathrm{~cm}^{3}$ each) and then dried over $\mathrm{MgSO}_{4}$. Removal of the solvent afforded the dimethyl ester of $N, N, N^{\prime}, N^{\prime}$-tetra(tertbutyloxycarbonyl) 2,5-diaminoadipic acid as a mixture of white solid diastereomers $(85 \%$ ) (found C, $55.68 \% ; \mathrm{H}$, $8.00 \%$; N, 4.42\%. Calcd for $\mathrm{C}_{28} \mathrm{H}_{48} \mathrm{~N}_{2} \mathrm{O}_{12} \mathrm{C}, 55.62 \%$; $\mathrm{H}$, $8.00 \% ; \mathrm{N}, 4.63 \%) ; \delta_{\mathrm{H}}\left(300 \mathrm{MHz} ; \mathrm{CDCl}_{3} ; \mathrm{Me}_{4} \mathrm{Si}\right) 1.48$, $1.50\left(36 \mathrm{H}, 2 \mathrm{~s}, \mathrm{CH}_{3} \mathrm{Boc}\right), 1.83-2.02\left(2 \mathrm{H}, \mathrm{m}, \beta \mathrm{CH} \mathrm{H}_{2}\right)$, 2.08-2.16 (2H, m, $\left.\beta \mathrm{CH}_{2}\right), 3.70\left(6 \mathrm{H}, \mathrm{s}, \mathrm{CH}_{3} \mathrm{OMe}\right), 4.84$ $4.87(1 \mathrm{H}, \mathrm{m}, \alpha \mathrm{CH}), 5.00-5.03(1 \mathrm{H}, \mathrm{m}, \alpha \mathrm{CH}) ; \delta_{\mathrm{C}}(75.4$ $\left.\mathrm{MHz} ; \mathrm{CDCl}_{3}\right)$ 26.10, 27.91, 52.13, 57.27, 83.19, 151.84, 171.04. The same procedure as described above was followed with Z- $\Delta \mathrm{Ala}(N$-Boc)-OMe $(167.7 \mathrm{mg}, 0.5 \mathrm{mmol})$ to give the dimethyl ester of $N, N^{\prime}$-bis(benzyloxycarbonyl) $N, N^{\prime}$-bis(tert-butyloxycarbonyl) 2,5-diaminoadipic acid as an oily mixture of diastereoisomers (78\%) (found $\mathrm{C}$, $60.26 \% ; \mathrm{H}, 6.26 \% ; \mathrm{N}, 4.05 \%$. Calcd for $\mathrm{C}_{34} \mathrm{H}_{44} \mathrm{~N}_{2} \mathrm{O}_{12} \mathrm{C}$, $60.70 \% ; \mathrm{H}, 6.59 \% ; \mathrm{N}, 4.16 \%) ; \delta_{\mathrm{H}}\left(300 \mathrm{MHz} ; \mathrm{CDCl}_{3}\right.$; $\left.\mathrm{Me}_{4} \mathrm{Si}\right) 1.42\left(18 \mathrm{H}, \mathrm{s}, \mathrm{CH}_{3} \mathrm{Boc}\right), 1.44$ (18H, s, CH 3 Boc), 1.80-2.18 (2H, m, $\left.\beta \mathrm{CH}_{2}\right), 2.19-2.43\left(2 \mathrm{H}, \mathrm{m}, \beta \mathrm{CH}_{2}\right), 3.61$ $\left(3 \mathrm{H}, \mathrm{s}, \mathrm{CH}_{3} \mathrm{OMe}\right), 3.62\left(3 \mathrm{H}, \mathrm{s}, \mathrm{CH}_{3} \mathrm{OMe}\right), 4.89-4.92$ $(1 \mathrm{H}, \mathrm{m}, \alpha \mathrm{CH}), 5.03-5.08(1 \mathrm{H}, \mathrm{m}, \alpha \mathrm{CH}), 5.22(2 \mathrm{H}, \mathrm{d}$, $\left.J=3.6, \mathrm{CH}_{2} \mathrm{Z}\right), 5.24\left(2 \mathrm{H}, \mathrm{d}, J=3.0, \mathrm{CH}_{2} \mathrm{Z}\right), 7.32-7.40$ $(10 \mathrm{H}, \mathrm{m}, \mathrm{Ar} H \mathrm{Z}) ; \delta_{\mathrm{C}}\left(75.4 \mathrm{MHz} ; \mathrm{CDCl}_{3}\right) 27.74,27.77$, $52.17,57.48,58.30,68.83,68.86,83.83,128.21,128.23$, $128.32,128.48,135.02,135.10,151.13,153,63,153.70$, $170.45,170.56$

10. Ferreira, P. M. T.; Maia, H. L. S.; Monteiro, L. S.; Sacramento, J. J. Chem. Soc., Perkin Trans. 1 2001, 3167-3174. 